\title{
Biological cycle of Tenuipalpus heveae Baker (Acari, Tenuipalpidae) on leaflets of three rubber tree clones
}

\author{
Reinaldo José Fazzio Feres ${ }^{1,2}$, Marcelo Del’'Arco ${ }^{3} \&$ Rodrigo Damasco Daud ${ }^{3}$
}

\begin{abstract}
${ }^{1}$ Departamento de Zoologia e Botânica, Instituto de Biociências, Letras e Ciências Exatas, Universidade Estadual Paulista, Rua Cristóvão Colombo, 2265, Jardim Nazareth, 15054-000 São José do Rio Preto-SP, Brazil. reinaldo@ibilce.unesp.br

${ }^{2}$ Pesquisador bolsista do CNPq.

${ }^{3}$ Programa de Pós-graduação em Biologia Animal, Universidade Estadual Paulista, Rua Cristóvão Colombo, 2265, Jardim Nazareth, 15054-000 São José do Rio Preto-SP, Brazil. Bolsista Capes. marcelodelarco@yahoo.com.br, rodrigodaud@yahoo.com.br
\end{abstract}

\begin{abstract}
Life cycle of Tenuipalpus heveae Baker (Acari, Tenuipalpidae) on leaflets from three rubber tree clones. The biological cycle of Tenuipalpus heveae Baker, 1945 (Tenuipalpidae), a potential rubber tree pest mite, was studied by the observation of individuals reared on leaflets of the clones GT 1, PB 235 and RRIM 600, in controlled environmental conditions. Three daily observations were done of 60 eggs on leaflets from each clone in order to verify the development of immature stages and the female oviposition. The fertility life table was constructed based in the collected data. Mites reared on PB 235 had faster rate of development, requiring less time in days, to double its population in number (TD), and had the highest values for egg production, female longevity, net reproductive rate $\left(R_{0}\right)$, intrinsic rate of natural increase $\left(r_{m}\right)$ and finite rate of increase $(\lambda)$. Lower reproductive values and the longest time necessary to reach adult stage were recorded for the mites on GT 1. In all studied clones, the deutonymphal phase had the highest viability, while the larval phase had the lowest, highlighted by the survivorship curve that indicated high mortality during this life stage. The clone PB 235 allowed the most suitable conditions for the development of $T$. heveae, followed by RRIM 600, while GT 1 was the less suitable substratum to rear this mite species.
\end{abstract}

KEYWORDS. Fertility life table; Hevea brasiliensis; phytophagous mite; plant resistance; survivorship.

\begin{abstract}
RESUMO. Ciclo de vida de Tenuipalpus heveae Baker (Acari, Tenuipalpidae) em folíolos de três clones de seringueira. O ciclo de vida de Tenuipalpus heveae Baker, 1945 (Tenuipalpidae), um potencial ácaro-praga da seringueira, foi estudado a partir de indivíduos criados sobre folíolos destacados dos clones GT 1, PB 235 e RRIM 600, em condições controladas. Três observações diárias foram realizadas, acompanhando-se o desenvolvimento de 60 ovos e de sua prole em folíolos de cada um dos clones, para verificação da oviposição das fêmeas e dos estágios de desenvolvimento. A partir dos dados obtidos, foi elaborada uma tabela de vida de fertilidade. Os ácaros criados sobre folíolos de PB 235 apresentaram rápido ciclo biológico, com menor tempo gasto, em dias, para duplicar sua população (TD) e os maiores valores para a produção de ovos, longevidade de fêmeas, taxa líquida de reprodução $\left(\mathrm{R}_{\mathrm{o}}\right)$, taxa intrínseca de crescimento populacional $\left(\mathrm{r}_{\mathrm{m}}\right)$ e taxa finita de crescimento populacional $(\lambda)$. Em GT 1 foram observados valores inferiores e o maior tempo de desenvolvimento necessário para atingir a fase adulta. Em todos os clones estudados a fase de maior viabilidade foi a deutoninfal, enquanto a menor, a larval, como evidenciado também pelas curvas de sobrevivência, que indicaram maior mortalidade nesse estágio juvenil. O clone PB 235 possibilitou melhor desenvolvimento para T. heveae, seguido por RRIM 600, enquanto que GT 1 foi o menos favorável ao desenvolvimento dessa espécie.
\end{abstract}

PALAVRAS-CHAVE. Ácaro fitófago; Hevea brasiliensis; resistência de plantas; sobrevivência; tabela de vida de fertilidade.

The rubber tree, Hevea brasiliensis Muell. Arg. (Euphorbiaceae), is native from the Amazon region, intensively grown in monocultures and producing high quality latex, which is used for manufacturing natural rubber. The world yield of latex in 2006 was 9,188,000 tons, of which approximately $78 \%$ was produced in Southeast Asia. In that same year, the yield in Brazil was 108,000 tons (1\%), even though the national consumption was 287,000 tons (IAC 2006).

Several ecological studies of mites associated with rubber trees have been conducted in different crops in the States of São Paulo and Mato Grosso (e.g. Ferla \& Moraes 2002; Demite \& Feres 2005; Hernandes \& Feres 2006a,b; Vis et al. 2006 and Daud \& Feres 2007). Not withstanding, relatively few studies were conducted concerning the biological aspects of the main phytophagous mites associated with this plant (Pontier et al. 2000; Ferla \& Moraes 2003a; Hernandes et al. 2006).

The female of the phytophagous mite Tenuipalpus heveae
Baker, 1945 (Tenuipalpidae) was described from rubber trees in the State of Pará more than six decades ago (Baker 1945). The male and the immature stages were described more recently by Pontier \& Flechtmann (1999) and Pontier \& Flechtmann (2000), respectively.

Only after 2000 T. heveae was reported as a potential pest of rubber trees (Pontier et al. 2000; Ferla \& Moraes 2002; Hernandes \& Feres 2006a, b; Vis et al. 2006; Daud \& Feres 2007). These mites are slow-moving and occur mainly on the lower surface of the leaflets, despite some individuals may be found on the upper surface when large infestations occur (Feres 2000). Oviposition usually takes place along the leaf veins or in shallow cavities of the leaflet surface and the eggs are glued to the substrate. Eggs are initially orange, becoming whitish before larvae eclosion. This species goes through two nymphal stages before reaching adulthood, and the females had mean life expectancy of 28.5 days when reared on the clone PB 260 (Pontier et al 2000).

Feres et al. (2002), Bellini et al. (2005), Hernandes \& 
Feres (2006a) and Vis et al. (2006), reported T. heveae as one the most abundant phytophagous mites on rubber tree crops in São Paulo State. Heavy infestations have also been registered (J. F. C. Benesi pers. comm.) in Goianésia, GO. According to Pontier et al. (2000), infestations of T. heveae in crops of Pontes e Lacerda, MT, resulted in intense defoliation, and therefore probably reduction of latex yield.

Ferla \& Moraes (2003b) demonstrated this species to be highly resistant to several agrochemicals often used for mite pest control. Evidences of such resistance had already been pointed out by Feres et al. (2002), who observed large populations of this species in a crop which received high rates of agrochemicals, in Taquaritinga, SP. This resistance, in addition to its high levels of abundance indicates that $T$. heveae has true potential for becoming a serious pest of rubber trees in some areas of Brazil.

Adding plants of resistant varieties in a crop might be a viable way to reduce the population of a given pest species in the field (Lara 1991). This technique could be easily applied in rubber tree crops, because hundreds of varieties (clones) are now available as result of studies developed along decades (Alvarenga \& Carmo 2008). Evidences that rubber tree clones present differential response to $T$. heveae attack have been already suggested by Daud \& Feres (2007), who observed higher abundance of these mites on the clones RRIM 600, PR 255 and PB 235, and lower numbers on PB 260, in southern Mato Grosso crops. No studies have been conducted to this date to detect differences in the susceptibility of rubber tree clones to T. heveae attack.

In the present paper the life cycle of $T$. heveae on the clones GT 1, PB 235 and RRIM 600 was studied, with life tables and fertility tables based on individuals reared on leaflets of the different clones. This allowed evaluate the potential growth of the population of this mite in each of those clones, whose are extensively cultivated in the State of São Paulo (Alvarenga \& Carmo 2008), and to determine the most and the less favorable clone for the development of that species.

\section{MATERIAL AND METHODS}

Essays were conducted at the Laboratory of Acarology, Universidade Estadual Paulista -UNESP, Campus of São José do Rio Preto, SP, in a rearing chamber with relative humidity of $70 \pm 10 \%$, light phase of $12 \mathrm{~h}, 28 \pm 1^{\circ} \mathrm{C}$ in light and $25 \pm 1^{\circ} \mathrm{C}$ in dark. These conditions are considered favorable for $T$. heveae development (Pontier et al. 2000).

The leaflets used for the rearing arenas and the life cycle study were taken from the level of the sixth to eighth axillary buds of plants from the experimental area of the Department of Zoology and Botany of UNESP, Campus of São José do Rio Preto, SP, under the same soil and climatic conditions and free of treatments with any agrochemicals. The rubber tree clones studied were GT 1, PB 235 and RRIM 600, approximately eight years old.

Rearing arenas. Tenuipalpus heveae females were collected from rubber tree leaflets of the clone RRIM 600 , from a crop in the municipality of Cedral, SP $\left(20^{\circ} 55^{\prime}\right.$ ' , $\left.49^{\circ} 26^{\prime} \mathrm{W}\right)$. The leaflets were observed under stereoscope, and the mites were removed with a fine brush and transferred to the rearing arenas.

The arenas constituted of rubber tree leaflets of the clones GT 1, PB 235 and RRIM 600, were washed with distilled water and kept suspended on rubber corks (2cm length and $1 \mathrm{~cm}$ in diameter), with the lower surface facing upwards. This procedure allowed maximal durability of the leaflets. This assemblage was placed inside a plastic tray (23 x $16 \mathrm{x}$ $6 \mathrm{~cm}$, Fig. 1) over a rectangle of nylon foam $2 \mathrm{~cm}$ thick, and kept moist with distilled water added daily. The margins of the leaflets were covered with stripes of wet cotton, whose prevented the mites in escaping. Since the survival of this species is higher in environments of low relative humidity (Pontier et al. 2000), the tray was kept open to avoid the excess of humidity. Arenas were kept in the rearing chamber for at least two weeks before starting the essays.

Arenas for life cycle studies. These arenas were fashioned as described previously and constituted by the same clones as the rearing arenas (Fig. 1).

The leaflets were divided in arenas of approximately $4 \mathrm{~cm}^{2}$, using stripes of paper tissue. Several leaflets were used until 60 arenas were achieved for each clone.

Five females $T$. heveae were put in each arena of the same clone as their rearing arenas. The mites and excessive eggs were removed after 12 hours, leaving only one egg per arena. This procedure was repeated until obtention of 60 eggs (replicas) for each rubber tree clone.

Arenas were observed daily under stereoscope at $8 \mathrm{am}$, $1 \mathrm{pm}$ and $6 \mathrm{pm}$ in order to verify the developmental stage of the mites. Events that occurred during night time were considered as occurring in the halfway of that interval. Upon reaching adulthood, the mites were transferred to new arenas and observed daily at 8 am and 6 pm for survivorship and oviposition accounting. No male was introduced into the life cycle arenas of females, because the low abundance of males in the rearing arenas.

At the first signs of damage to the leaflets, the mites were transferred to new arenas. In order to avoid direct manipulation of the mites and therefore interfere in their development the individuals were transferred to the new arena on a small piece of the substrate.

Mites found dead in the arenas were mounted in microscopy slides using Hoyer's medium (Flechtmann 1975) and deposited in the collection of Acari of DZSJRP (slides 6877 to 6881) (http://www.splink.cria.org.br), from the Departamento de Zoologia e Botânica, Universidade Estadual Paulista (UNESP), São José do Rio Preto, SP.

Data analyses and statistics. The experiment was entirely randomized, being 60 replicas (eggs) for each treatment (clone).

The average duration of each life history stage, female oviposition rate and length of each reproductive stage of $T$. heveae on the selected rubber tree clones were analyzed using ANOVA and then complemented with Tukey test $a$ posteriori for means differentiating, except for the average duration of the deutonymphal stage, which was compared using KruskalWallis test, because of its non-parametrical distribution, even 

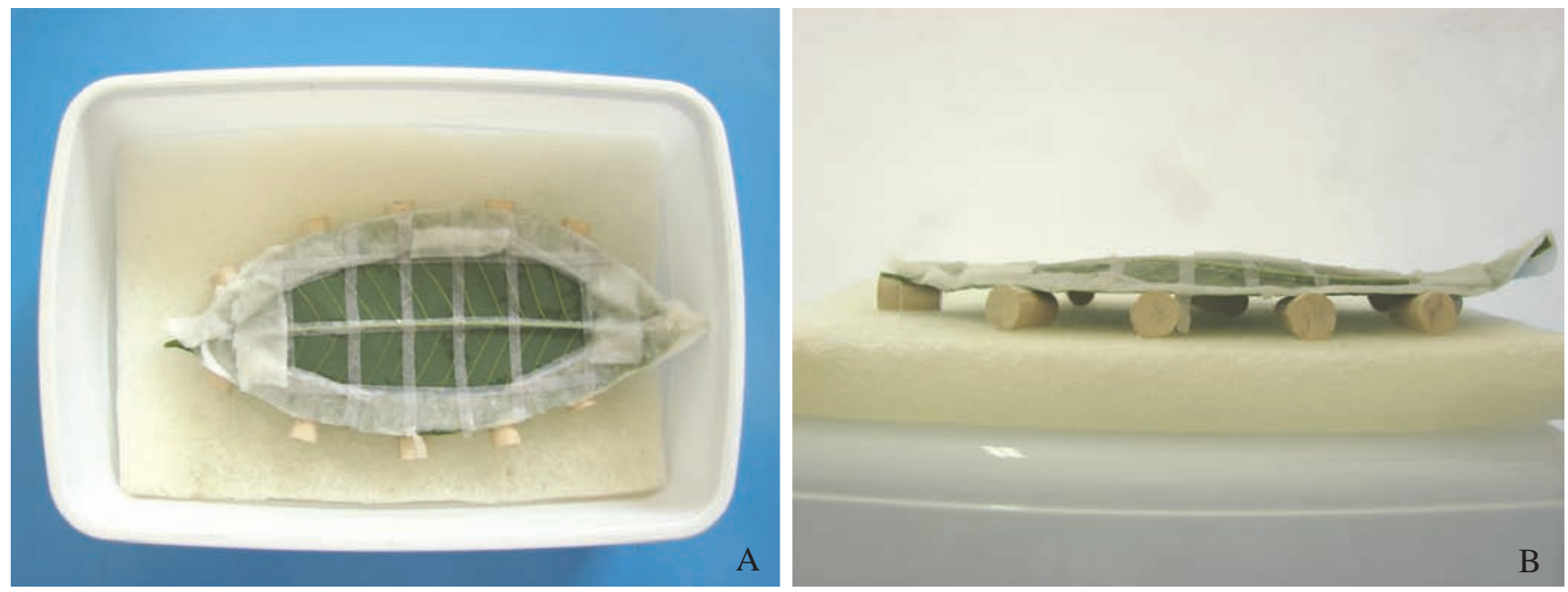

Fig. 1. Arena for the study of life cycle of T. heveae: (A) viewed from above, (B) lateral view.

after attempts of transformation of data (Zar 1999). Males were not included in the analysis due to their low number.

The viability of different immature stages was compared using G-test, with corrections of Bonferroni $(\alpha / \mathrm{n})$ for paired comparisons (Zar 1999). The survivorship curves for the three populations of $T$. heveae were estimated from the function of cumulative proportion surviving of Kaplan-Meier and compared through the Peto and Peto's generalized Wilcoxon test, extended for comparisons of more than two samples (Hosmer Jr. \& Lemeshow 1999). Dead mites found in the paper tissue stripes or accidentally dead due to handling were considered as censored data in this latter test.

The fertility life table of $T$. heveae was built considering females of the studied generation, which allowed to calculate the net reproductive rate $\left(\mathrm{R}_{\mathrm{o}}\right)$, mean generation time $(\mathrm{T})$, intrinsic rate of population increase $\left(\mathrm{r}_{\mathrm{m}}\right)$, finite rate of population increase $(\lambda)$ and average time in days for doubling the population in number (double time - DT). These parameters were calculated using the software SAS (SAS Institute 1999-2001), through the model created by Maia et al. (2000), which uses the method of Jackknife to estimate the intervals of mean confidence. It allows comparisons between the pairs of treatments through Student T-test. The sex ratio considered for elaborating the life table was based on the adults obtained from the studied generation.

\section{RESULTS}

Life cycle of T. heveae. The incubation time was the longest of all life history stages, with average duration of 9 to 10 days from oviposition to eclosion of larvae, whereas the shortest stage was the protonymph, with 4 to 5 days (Table I).

Eggs of mites reared on GT 1 leaflets had the shortest incubation time. Distinctively on that clone we observed the longest time to reach the adult stage, with average of 26.7 days from oviposition to adult stage. That high value resulted mainly from the long duration of the deutonymphal stage (7.1 days, $\mathrm{H}=10.3, \mathrm{GL}=2, p=0.006$ ) when compared with the mites reared on the clones PB 235 and RRIM 600. The mites reared on PB 235 reached adulthood in shorter time (24.1 days), although the duration of the incubation time of eggs was longer, which was compensated by the shorter deutonymphal stage (4.7 days). The average duration of the larval and protonymphal stages was not significantly different between the mites reared on the three clones (Tables I and II).

The females on PB 235 and RRIM 600 had adult longevity about 1.8 times the duration of those on GT 1, with a total average of 29 days (Tables I and II). This longevity was a result of the longer time of oviposition phase by the females in the former two clones (25 days in average), since the pre and post oviposition periods did not significantly vary between the different treatments (Tables I and II).

About $78 \%$ and $82 \%$ of the individuals that reached adulthood on the clones PB 235 and RRIM 600, respectively, were females. No male was observed on GT 1 (Table I).

Reproductive parameters of females. Females reared on PB 235 had the highest daily (1 egg/female/day) and oviposition rate (30.1 eggs/female), whereas those reared on GT 1 had the lowest (9 eggs/female and $0.6 \mathrm{egg} /$ female/day). On RRIM 600 , the females had an intermediate oviposition rate (21.9 eggs/female), although the average daily oviposition was similar to those reared on GT 1 (Tables I and II).

Daily variation was observed in the number of eggs laid by females, especially for those reared on GT 1 . The peak of oviposition on PB 235 and RRIM 600 (1.8 and 1.2 egg/ female, respectively) occurred in the seventh day, whereas on GT 1 it was only after the $19^{\text {th }}$ day (1 egg/day) lasting until the $24^{\text {th }}$ day in that value. In PB 235, the daily posture was high until the $22^{\text {nd }}$ decreasing in subsequent days, and on RRIM 600 until the $25^{\text {th }}$ day. In this last clone, however, three drops were observed in the daily oviposition before that period, in the $12^{\text {th }}, 17^{\text {th }}$ and $22^{\text {nd }}$ days (Fig. 2).

Immatures viability and survival. The deutonymphal stage had the highest viability in all clones studied, with $100 \%, 94.7 \%$ and $77.7 \%$ when reared on the clones RRIM 600 , PB 235 and GT 1, respectively. On the other hand, the 


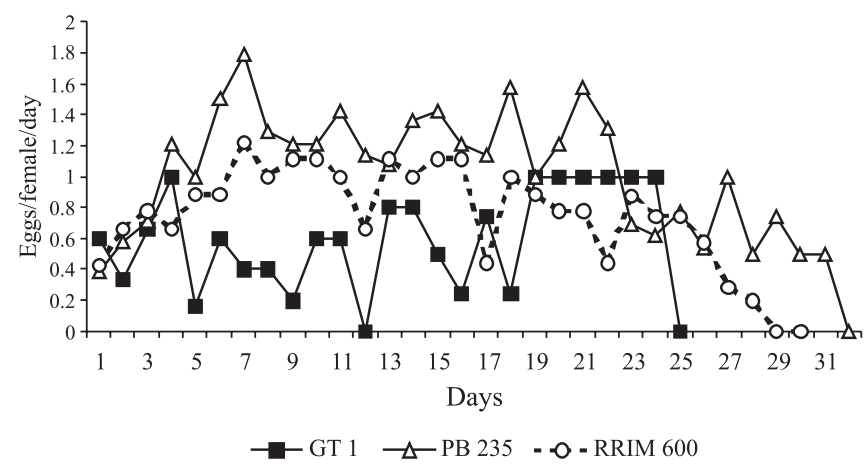

Fig. 2. Average number of eggs laid per day per female of $T$. heveae, reared on leaflets of three rubber tree clones, in BOD with relative humidity of $70 \pm 10 \%$, light phase of $12 \mathrm{~h}, 28 \pm 1^{\circ} \mathrm{C}$ in light and $25 \pm 1^{\circ} \mathrm{C}$ in dark.

larval stage had the lowest, with $43.1 \%$ on PB 235 and $48 \%$ on both RRIM 600 and GT $1(\mathrm{G}=10.3,23.4$ and 21.2 on GT 1, PB 235 and RRIM 600, respectively, $p<0.01$ ). No significant differences were observed when the viability of each life history stage was compared between mites reared on the different clones (Fig. 3).

The estimated survivorship curves built using the KaplanMeier function had similar patterns and pointed to a high mortality of this species during larval stage, mostly on the first five days from eclosion (Fig. 4). After that period, the survivorship was stable and only reduced after the $28^{\text {th }}$ day, representing the end of the female reproductive period (Fig. 4). The survivorship curves did not differ significantly for the mites reared on the three clones (Wilcoxon test, $\chi^{2}=0,35$, GL $=2, p=0,84$ ).

Fertility life table. The mean generation time $(\mathrm{T})$ was the only parameter of the life table which did not vary significantly between mites reared on the three rubber tree clones (Table III). The average time was 27.6 days on PB 235, 29.03 days on RRIM 600 and 30.1 days on GT 1. The value of the net reproductive rate $\left(\mathrm{R}_{\mathrm{o}}\right)$, intrinsic rate of population increase $\left(\mathrm{r}_{\mathrm{m}}\right)$

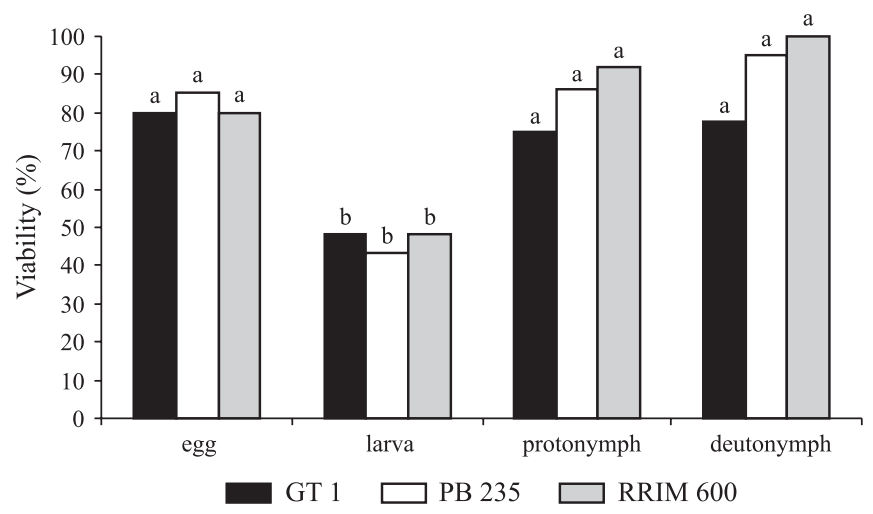

Fig. 3. Viability (\%) of $T$. heveae in the immature stages, reared on leaflets from three rubber tree clones. Different letters between the bars means statistical difference at the $5 \%$ level of probability by the G-test.

and finite rate of population increase $(\lambda)$ were significantly higher on PB 235, whereas the lowest values were observed on the mites reared on GT 1. Besides, the shortest average time for doubling the population was observed on the clone PB 235 (DT = 11.2 days, table III).

\section{DISCUSSION}

According to the data obtained from the essays it is possible to conclude that clone PB 235, followed by RRIM 600 , enabled the most favorable conditions for the T. heveae development, whereas GT 1 was the least favorable for this mite species. When reared on the former it had shorter life cycle and longer longevity of females during the adult stage, which indicates that these clones may offer more favorable nutritional conditions and/or less amount of natural defenses against herbivory by this mite species, in comparison to GT 1.

The higher susceptibility of the clone PB 235 to this mite is confirmed by the higher values found on several parameters: the average total oviposition, number of eggs/

Table I. Average time (standard error), in days, of immature stages and female longevity, total number of eggs and daily egg production, and female proportion of $T$. heveae reared on three rubber tree clones in BOD with relative humidity of $70 \pm 10 \%$, light phase of $12 \mathrm{~h}, 28 \pm 1^{\circ} \mathrm{C}$ in light and $25 \pm 1^{\circ} \mathrm{C}$ in dark.

\begin{tabular}{|c|c|c|c|c|c|c|}
\hline \multirow[t]{2}{*}{ Biological parameters } & \multicolumn{2}{|c|}{ GT 1} & \multicolumn{2}{|c|}{ PB 235} & \multicolumn{2}{|c|}{ RRIM 600} \\
\hline & Mean (SE) & $\mathrm{n}$ & Mean (SE) & $\mathrm{n}$ & Mean (SE) & $\mathrm{n}$ \\
\hline IMMATTURES & & & & & & \\
\hline incubation time of eggs & $9.3(0.1) b^{*}$ & 48 & $10.1(0.1)$ a & 52 & $9.9(0.2)$ a & 48 \\
\hline larva & $5.9(0.4)$ a & 12 & $5.2(0.3)$ a & 22 & $5.7(0.3)$ a & 12 \\
\hline protonymph & $5.0(0.4)$ a & 9 & $4.2(0.2)$ a & 19 & $4.0(0.2)$ a & 11 \\
\hline deutonymph & $7.1(0.9)$ a & 7 & $4.7(0.2) \mathrm{b}$ & 18 & $5.4(0.3)$ a,b & 11 \\
\hline $\begin{array}{l}\text { egg - female } \\
\text { female }\end{array}$ & $26.7(1.0)$ a & 7 & $24.1(0.3) \mathrm{b}$ & 18 & $25.6(0.5) a, b$ & 11 \\
\hline Longevity in adult stage & $15.7(3.0) \mathrm{b}$ & 7 & $28.9(0.7)$ a & 14 & $29.0(0.8)$ a & 9 \\
\hline pre-oviposition & $4.8(2.5) \mathrm{a}$ & 7 & $2.9(0.4) \mathrm{a}$ & 14 & $2.8(0.4) \mathrm{a}$ & 9 \\
\hline oviposition & $12.3(2.5) \mathrm{b}$ & 6 & $25.2(0.6)$ a & 14 & $25.3(1.0) \mathrm{a}$ & 9 \\
\hline post-oviposition & $2.5(1.5) \mathrm{a}$ & 3 & $2.8(0.4) \mathrm{a}$ & 9 & $3.1(0.6) \mathrm{a}$ & 9 \\
\hline eggs/female/day & $0.6(0.07) \mathrm{b}$ & 6 & $1.0(0.07)$ a & 14 & $0.7(0.06) \mathrm{b}$ & 9 \\
\hline total eggs/female & $9.0(1.6)$ c & 6 & $30.1(1.7)$ a & 14 & $21.9(1.2) \mathrm{b}$ & 6 \\
\hline Proportion of females (\%) & 100 & - & 78 & - & 82 & - \\
\hline
\end{tabular}

\footnotetext{
* Numbers followed by different letters between the columns means statistical differences at $5 \%$ level of probability by the Tukey test.
} 


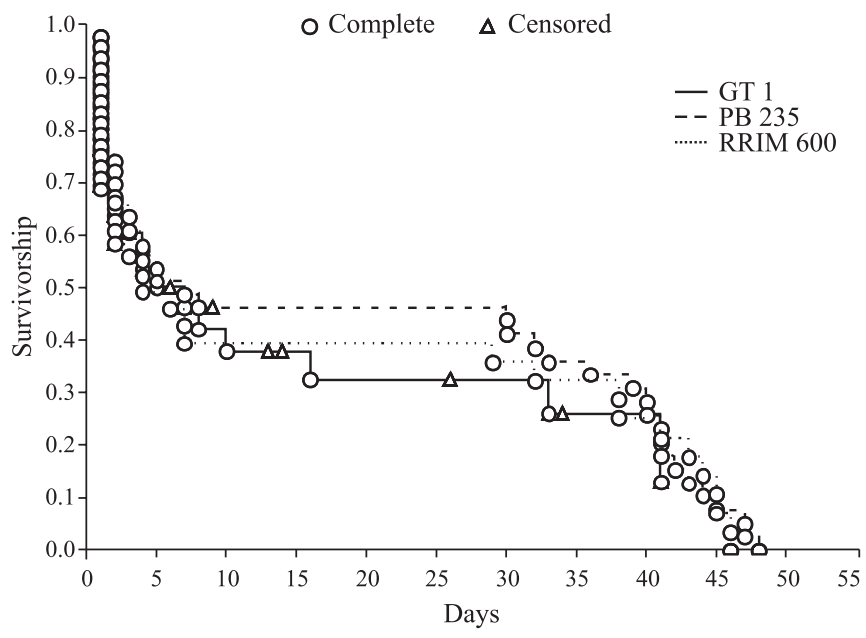

Fig. 4. Survivorship curves determined by the function of cumulative proportion surviving of Kaplan-Meier for T. heveae populations reared on three rubber tree clones.

female/day, intrinsic rate of increase, finite rate of increase, net reproductive rate and the shorter time required for doubling its population. These parameters were considered by Begon et al. (2006) as the ones which best represent the population ability to increase in number, under certain nutritional and climatic conditions.

Although the number of eggs laid daily per female did not differ, the total average number of eggs on RRIM 600 was higher in comparison to GT 1. Besides, the intermediate values of the fertility life table confirm RRIM 600 as the second most favorable amongst the studied clones for the $T$. heveae development.

The susceptibility of the clone PB 235 to the T. heveae attack has also been reported elsewhere. Daud \& Feres (2007) verified that the clones PB 235, PR 255 and RRIM 600 were the most vulnerable to the attack of this phytophagous mite in crops in the southern State of Mato Grosso. Monteverde (2006) observed higher level of infestation in seedlings of PB 235 than in RRIM 600, in a study conducted in greenhouse. The susceptibility of a same cultivar to the attack by phytophagous pests can also change according to the soil type and climatic conditions and also to the host age (Lara 1991).

Some biological parameters found in the present study were similar to those reported by Pontier et al. (2000), who studied the life cycle of the same mite species reared on PB 260 . They also reported the longest life history stage as the egg (average of 13.7 days), and the protonymphal and larval as the shortest stages (averages of 4.6 and 4.9 days, respectively).
Table II. Results of ANOVA on different biological parameters of $T$. heveae reared on three rubber tree clones. Legends: (DF) degree of freedom, (MS) mean square, $(F)$ ANOVA value and $(P)$ error probability at $5 \%$ level.

\begin{tabular}{lcccc}
\hline Parameters & DF & $M S$ & $F$ & $P$ \\
\hline incubation time & 2 & 8.03 & 8.41 & $<0.001$ \\
larva* & 2 & 1.28837 & 0.8296 & 0.44 \\
protonymph * & 2 & 2.6964 & 3.1635 & 0.06 \\
deutonymph ** & - & - & - & - \\
egg-adult females & 2 & 19.5 & 6.451 & 0.004 \\
longevity & 2 & 470.55 & 24.23 & $<0.001$ \\
pre-oviposition & 2 & 9.2378 & 1.0951 & 0.35 \\
oviposition & 2 & 397.67 & 31.172 & $<0.001$ \\
post-oviposition & 2 & 0.42778 & 0.1549 & 0.86 \\
eggs/female/day & 2 & 1.20246 & 11.065 & $<0.001$ \\
total eggs/female & 2 & 943.16 & 32.617 & $<0.001$ \\
\hline
\end{tabular}

* Without statistical difference;

** Compared by Kruskall-Wallis test $(\mathrm{H}=10.3, \mathrm{GL}=2, p=0.006)$.

Moreover, they registered similar periods of pre-oviposition, with average of 4.4 days, as well as oviposition with average of 23.8 days and post-oviposition of 0.4 day. Their values of intrinsic rate $\left(\mathrm{r}_{\mathrm{m}}\right)$ and finite rate of increase $(\lambda)$ were 0.08 and 1.08 , respectively.

The high rate of mortality during the larval stage was also verified by Pontier et al. (2000), with loss of $46 \%$ of individuals in that stage. Similar results were also obtained by Chiavegato (1986) studying Brevipalpus phoenicis Geijskes, 1939 (Tenuipalpidae) on citrus, which indicates that this stage is probably the most vulnerable to perishing in laboratory conditions. Another possible explanation for the high mortality during larval stage is the high moisture inside the trays (about 70\%), since the peaks of infestation in the field were registered during the dry season, from April to May, in Southeastern and Northwestern parts of São Paulo and Southeastern Mato Grosso States (Feres et al. 2002; Bellini et al. 2005; Hernandes \& Feres 2006a; Vis et al. 2006; Daud \& Feres 2007). Moreover, Pontier et al. (2000) observed higher rates of survival of $T$. heveae when reared in opened trays than when in covered trays, resulting in a higher relative humidity on these latter trays. These results, therefore, indicate that this species has better development in laboratory conditions of lower relative humidity.

On the other hand, populations of T. heveae in the field might have patterns of survival similar to the results observed experimentally in the laboratory. The survivorship curves on the three clones using the function of Kaplan-Meier (Fig. 4) were of the type III, according to the classification of Pearl (1928) apud Begon et al. (2006), which means that

Table III. Average values (standard error) of net reproductive rate $\left(R_{0}\right)$, mean generation time $(T)$, intrinsic rate of population increase ( $\left.r_{m}\right)$, finite rate of population increase $(\lambda)$ and doubling time (DT) for T. heveae rearing on leaflets of clones GT 1, PB 235 and RRIM 600.

\begin{tabular}{cccccc}
\hline Clones & $\begin{array}{c}\mathrm{T} \\
\text { (days) }\end{array}$ & $\lambda$ & $\begin{array}{c}\mathrm{r}_{\mathrm{m}} \\
(+)(+)^{-1}(\mathrm{day})^{-1}\end{array}$ & $\begin{array}{c}\mathrm{R}_{\mathrm{o}} \\
(++)\left(\begin{array}{l}(+)^{-1} \\
(\text { days })\end{array}\right.\end{array}$ \\
\hline GT 1 & $30.1(1.7) \mathrm{a}^{*}$ & $1.0(0.006) \mathrm{c}$ & $0.0016(0.006) \mathrm{c}$ & $1.05(0.2) \mathrm{c}$ & $2401.2(701.5) \mathrm{a}$ \\
PB 235 & $27.6(0.8) \mathrm{a}$ & $1.06(0.003) \mathrm{a}$ & $0.06(0.003) \mathrm{a}$ & $5.4(0.3) \mathrm{a}$ & $11.2(0.6) \mathrm{c}$ \\
RRIM 600 & $29.03(0.7) \mathrm{a}$ & $1.03(0.002) \mathrm{b}$ & $0.03(0.002) \mathrm{b}$ & $2.7(0.1) \mathrm{b}$ & $20.2(1.1) \mathrm{b}$ \\
\hline
\end{tabular}

* Numbers followed by different letters between the lines mean statistical differences at $5 \%$ level of probability by the Student T-test. 
the population of this species has high mortality rate during juvenile stages, but its survivorship raises in subsequent stages. This survivorship pattern is widely found on several animal populations, especially in species with high reproductive rate such as many arthropods (Odum \& Barrett 2007; Begon et al. 2006).

Pontier et al. (2000) observed that $85 \%$ of the individuals that reach adulthood when reared on PB 260 were females, whereas in the present study we found $78 \%$ and $82 \%$ of females on PB 235 and RRIM 600, respectively, and no male was found on GT 1. Feres (2000) and Ferla \& Moraes (2002) also reported males of that species as being very rare in surveys in different rubber tree crops.

According to Awmack \& Leather (2002), chemicals found on the leaves (e.g. levels of nitrogen, carbon, minerals, defensive compounds) may affect positively or negatively the growth, development time and amount of offspring of the herbivorous arthropods. It is reasonable to suspect that the clones studied might have differences in their leaf chemistry, which would explain the different pattern found on the life cycle, female oviposition and population growth of $T$. heveae. Regardless of such chemicals that may have influenced the development, it was possible to verify that the clones PB 235 and RRIM 600 are more susceptible to the attack of $T$. heveae when compared to the clone GT 1. Increasing the area of cultivation of this latter clone in regions of large infestations of $T$. heveae might be an alternative to reduce yield losses due to this mite, since other desirable features are also considered, such as latex yield, adaptations to climatic and soil conditions.

Acknowledgements. To Dr. Carlos H.W. Flechtmann (USP, Piracicaba) for critically review of the manuscript. To Drs. Marineide R. Vieira (UNESP, Ilha Solteira) and Marcel Tanzini (UNILESTE, Piracicaba) for the critics and suggestions to the first version of the manuscript. To Dr. Aline de H.N. Maia (Embrapa Meio Ambiente, Jaguariúna) and Dr. Fernando Ferrari (Depto. de Ciências de Computação e Estatística, UNESP, S. J. do Rio Preto) for helping in the statistic analysis of the fertility life table and survival, respectivelly.

\section{REFERENCES}

Alvarenga, A. de P. \& C. A. F. S. do Carmo. 2008. Seringueira. Viçosa, Epamig, $894 \mathrm{p}$.

Awmack, C. S. \& S. R. Leather. 2002. Host plant quality and fecundity in herbivorous insects. Annual Review of Entomology 47: 817-844.

Begon, M.; C. R. Townsend \& J. L. Harper. 2006. Ecology: From individuals to ecosystems. $4^{\text {th }}$ edition, Oxford, Blackwell Publishing Ltd, 738 p.

Baker, E. W. 1945. Mites of the genus Tenuipalpus (Acarina: Tenuipalpidae). Proceedings of the Entomological Society of Washington 47: 33-38.

Bellini, M. R.; G. J. de Moraes \& R. J. F. Feres. 2005. Ácaros (Acari) de dois sistemas de cultivo da seringueira no noroeste do Estado de São Paulo. Neotropical Entomology 34: 475-484.

Chiavegato, L. G. 1986. Biologia do ácaro Brevipalpus phoenicis em citrus. Pesquisa Agropecuária Brasileira 21: 813-816.

Daud, R. D. \& R. J. F. Feres. 2007. Dinâmica populacional de ácaros fitófagos (Acari, Eriophyidae, Tenuipalpidae) em seis clones de seringueira no sul do Estado de Mato Grosso. Revista Brasileira de Entomologia 51: 377-381.

Demite, P. R. \& R. J. F. Feres. 2005. Influência de vegetação vizinha na distribuição de ácaros em seringal (Hevea brasiliensis Muell. Arg.,
Euphorbiaceae) em São José do Rio Preto, SP. Neotropical Entomology 34: 829-836.

Feres, R. J. F. 2000. Levantamento e observações naturalísticas da acarofauna (Acari, Arachnida) de seringueiras cultivadas (Hevea spp., Euphorbiaceae) no Brasil. Revista Brasileira de Zoologia 17: 157-173.

Feres, R. J. F.; D. C. Rossa-Feres; R. D. Daud \& R. S. Santos. 2002. Diversidade de ácaros (Acari, Arachnida) em seringueiras (Hevea brasiliensis Muell. Arg., Euphorbiaceae) na região noroeste do Estado de São Paulo, Brasil. Revista Brasileira de Zoologia 19: 137-144.

Ferla, N. J. \& G. J. de Moraes. 2002. Ácaros (Arachnida, Acari) da seringueira (Hevea brasiliensis Muell. Arg.) no Estado do Mato Grosso, Brasil. Revista Brasileira de Zoologia 19: 867-888.

Ferla, N. J. \& G. J. de Moraes. 2003a. Ciclo biológico de Calacarus heveae Feres, 1992 (Acari, Eriophyidae). Revista Brasileira de Entomologia 47: 399-402.

Ferla, N. J. \& G. J. de Moraes. 2003b. Efeitos de diferentes concentrações de acaricidas e inseticidas-acaricidas sobre Calacarus heveae Feres, 1992 e Tenuipalpus heveae Baker, 1945 (Acari: Eriophyidae e Tenuipalpidae). Acta Biologica Leopoldensia 25: 179-185.

Flechtmann, C. H. W. 1975. Elementos de Acarologia. São Paulo, Livraria Nobel S. A., 344 p.

Hernandes, F. A. \& R. J. F. Feres. 2006a. Diversidade e sazonalidade de ácaros (Acari) em seringal (Hevea brasiliensis, Muell. Arg.) no noroeste do estado de São Paulo. Neotropical Entomology 35: 523-535.

Hernandes, F. A. \& R. J. F. Feres. 2006b. Review about mites (Acari) of rubber trees (Hevea spp., Euphobiaceae) in Brazil. Biota Neotropica 6: $1-24$.

Hernandes, F. A.; R. J. F. Feres \& F. Nomura. 2006. Biological cycle of Lorryia formosa (Acari, Tydeidae) on rubber tree leaves: a case of thelytoky. Experimental and Applied Acarology 38: 237-242.

Hosmer Jr., D. W. \& S. Lemeshow. 1999. Applied survival analysis: Regression modeling of time to event data. New York, John Wiley \& Sons Inc., $386 \mathrm{p}$.

Instituto Agronômico de Campinas (IAC). 2006. Programa seringueira: Importância da borracha natural. Disponível em: http://www.iac.sp.gov. br/centros/centro_cafe/seringueira/importcult.htm. Acesso em 21 de novembro de 2008.

Lara, F. M. 1991. Princípios de resistência de plantas a insetos. São Paulo, Ícone, $336 \mathrm{p}$.

Maia, A. H. N.; A. J. B. Luiz \& C. Campanhola. 2000. Statistical inference on associated fertility life table parameters using Jackknife technique: Computational aspects. Journal of Economic Entomology 93: 511-518.

Monteverde, M. S. 2006. Comportamento de clones de seringueira quanto ao ataque de Tenuipalpus heveae Baker (Acari: Tenuipalpidae) e potencial de Euseius citrifolius Denmark \& Muma (Acari: Phytoseiidae) como seu predador. Dissertação de Mestrado em Agronomia. Ilha Solteira, Universidade Estadual Paulista, 87 p.

Odum, E. P. \& G. W. Barrett. 2007. Fundamentos de Ecologia. São Paulo, Thomson Learning, $612 \mathrm{p}$.

Pontier, K. J. B. \& C. H. W. Flechtmann. 1999. Description of male Tenuipalpus heveae Baker, 1945 (Acari: Prostigmata: Tenuipalpidae). International Journal of Acarology 25: 293-296.

Pontier, K. J. B. \& C. H. W. Flechtmann. 2000. Description of the immature stages of Tenuipalpus heveae Baker, 1945 (Acari, Prostigmata, Tenuipalpidae). Systematic and Applied Acarology 5: 77-81.

Pontier, K. J. B.; G. J. de Moraes \& S. Kreiter. 2000. Biology of Tenuipalpus heveae (Acari, Tenuipalpidae) on rubber tree leaves. Acarologia 41: $423-427$.

SAS Institute. 1999-2001. SAS/STAT User's guide, version 8.02, TS level 2MO. SAS Institute Inc., Cary, NC.

Vis, R. M. J. De ; G. J. de Moraes \& M. R. Bellini. 2006. Mites (Acari) of rubber trees (Hevea brasiliensis Muell. Arg., Euphorbiaceae) in Piracicaba, State of São Paulo, Brazil. Neotropical Entomology 35: $112-120$.

Zar, J. H. 1999. Biostatistical analysis. 4aed., New Jersey, Prentice-Hall, Inc., 663 p. 